\title{
PERAN PSIKOLOGI PENDIDIKAN SEBAGAI UPAYA MEREDAM \\ PENYEBARAN HOAKS
}

\author{
Mahmud Zain \\ Pascasarjana UIN Sunan Kalijaga Yogyakarta \\ mahmoed.aein18@gmail.com
}

\begin{abstract}
Nowadays everyone has a gadget and social media account, such as Whats App, Facebook, Twitter, Instagram, etc. This can make anyone addicted of technology and make them happy, comfortable, even stress. Therefore, school as a constitutional education obligate to anticipate the spreading of hoax. One of the ways is the role of educational psychology as education process of material learning related to technology. Technology supports all sorts of ability in managing the information gotten by students, such as; understanding, analysis, and critical thinking. Learning process of technology can used by teacher to give instruction in order that the students can managing the information, so that, they can behaving critically and avoiding of spreading of hoax.
\end{abstract}

\section{Keywords: Educational Psychology, Hoax}

\begin{abstract}
Abstrak
Saat ini setiap orang memiliki gadget dan akun media sosial, seperti WhatsApp, Facebook, Twitter, Instagram, dll. Hal ini dapat membuat siapa saja kecanduan teknologi dan membuat mereka senang, nyaman, bahkan stres. Oleh karena itu, sekolah sebagai pendidikan konstitusional wajib mengantisipasi penyebaran hoax. Salah satu caranya adalah dengan peran psikologi pendidikan sebagai proses pendidikan materi pembelajaran yang berkaitan dengan teknologi. Teknologi mendukung segala macam kemampuan dalam mengelola informasi yang diperoleh siswa, seperti; pemahaman, analisis, dan pemikiran kritis. Proses pembelajaran teknologi dapat dimanfaatkan oleh guru untuk memberikan arahan agar siswa dapat mengelola informasi, sehingga mereka dapat bersikap kritis dan terhindar dari penyebaran hoax.
\end{abstract}

\section{Kata Kunci : Psikologi Pendidikan, Hoaks}




\section{Pendahuluan}

Komunikasi merupakan bagian yang tidak terpisahkan dari seluruh aktivitas manusia, baik manusia sebagai individu maupun sebagai kelompok. Identitas diri manusia sebagai mahluk sosial mengaharuskan manusia berhubungan dengan orang lain hal ini dikarenakan manusia membutuhkan orang lain dalam memenuhi kebutuhan hidupnya. Bahkan dalam sebuah penelitian mengungkapkan bahwa $70 \%$ waktu kita gunakan untuk berkomunikasi. Sementara komunikasi juga dapat menentukan kualitas hidup kita. ${ }^{1}$

Dewasa ini komunikasi antar manusia satu dengan yang lain sangat mudah karena dibantu oleh teknologi dan informasi. Kecepatan teknologi dan informasi membuat kebutuhan seseorang dapat tercapai

1 Jalaluddin rahmat, Psikologi Komunikasi (Bandung : Remaja Rosdakarya, 2008), vii. dalam waktu yang relatif singkat. Teknologi telah memberikan semua jenis kebutuhan yang diinginkan oleh manusia dengan beberapa aplikasi yang terdapat didalamnya untuk memudahkan seseorang untuk berinteraksi diantaranya adalah Whatshap, Facebook, Twitter, Instagram, dan sebagainya.

Implikasi teknologi dan informasi memang memberikan manfaat positif yang begitu besar misalnya seseorang berkomunikasi dan mendapatkan informasi dengan begitu cepat dalam hitungan detik terkait peristiwa fenomena yang terjadi di seluruh muka bumi seperti bencana alam, kebakaran. Akan tetapi teknologi dan informasi juga menimbulkan dampak negatif terhadap media sossial dalam kehidupan manusia. Media merupakan alat kelompok dominan utnuk memanipulasi dan mengukuhkan kehadirnay sembari memarjinalkan 


\section{Mahmud Zain}

kelompok yang tidak dominan. ${ }^{2}$ Akibatnya media sosial turut menyumbangkan perbuatan negatif seperti meningkatnya kekerasan, korupsi, pelecehan, penipuan dan berita bohong yang dikenal dengan istilah HOAKS.

Fenomena hoak dapat kita kenali dari beberapa hal diantaranya yaitu sumber beritanya berasal dari pihak yang tidak dapat dipercaya, tidak ada tautan ke sumber resmi, berita tersebut dari situs yang tidak jelas siapa penanggung jawabnya misalnya dari perorangan, lembaga, atau lainnya atau dari situs yang tidak dapat dipastikan apakah memiliki kredibilitas/reputasi berita yang cukup baik, gambar, foto atau video yang dipakai merupakan rekayasa, atau bahkan tidak nyambung dengan beritanya, menggunakan kalimat yang provokatif, sehingga mudah memengaruhi pembacanya,

2 Eriyanto, Analisis Wacana Pengantar Analisis Teks Media (Yogyakarta: Lkis, 2001), 22. mengandung unsur politis dan SARA. ${ }^{3}$

Di Indonesia pada saat ini mengalami permasalahan sangat serius yaitu salah satunya adalah maraknya hoaks di masyarakat. berdasarkan hasil lembaga survei lingkaran survei Indonesia (LSI) Denny JA pada tahun 2018 yang dilakukan pada 10-19 Oktober 2018 mencatat bahwa 75 persen publik khawatir dengan kian maraknya hoaks, dari jumlah 1.200 responden diseluruh Indonesia.

Fenomena berita hoaks menjadi kekhawatiran bersama seluruh elemen masyarakat, terutama pendidik hal ini dikarenakan pendidik memiliki kewajiban sosial untuk bisa mengarahkan dan mengedukasi peserta didik agar tidak gagap teknologi dan informasi dalam menggunakan media sosial. ${ }^{4}$ Oleh

\footnotetext{
3 Lusiana Monohevita, "Stop Hoax! Setelah Tahu Sebuah Informasi Adalah Hoax, Apakah Anda Masih Ingin Menyebarkannya?", Uilib.Berkala, Vol. 3, No. 3, (September, 2017), 7.

${ }^{4}$ Ari Rizki Nugraha, Gerakan Literasi Media Di Sekolab Sebagai Upaya Meminimal-
} 
karena itu edukasi dalam penggunaan media sosial mestinya digalakkan dalam rangka untuk meminimalisir sekaligus menghilangkan virus hoax dalam kehidupan berbangsa dan bernegera.

Pencegahan penyebaran hoaks harus dimulai dari lembaga pendidikan mengingat Lembaga Pendidikan adalah benteng utama dalam mencetak generasi yang produktif, unggul serta maju dengan demikian lemabaga Pendidikan juga mempunyai tanggung jawab moral dalam masalah penyebaran berita hoaks yang terjadi di masyarakat yang sangat masif dan merajalela di media sosial. Sementara dalam lembaga pendidikan upaya pendidik maupun pemerintah dalam menangkal penyebaran berita bohong masih belum banyak dil-

isir Penyebaran Hoaks Melalui Media Sosial, (Bandung: Universitas Pendidikan Indonesia, 2018), 69. akukan sehingga peserta didik menjadi korban bahkan pelaku dari penyebar berita bohong.

Dalam konteks ini penulis ingin membahas peran psikologi pendidikan sebagai upaya meredam penyebaran hoaks di masyarakat dengan melaui pendekatan pembelajaran dengan dua kategori yaitu pendekatan perilaku dan pendeka$\tan$ kognitif.

Adapun pendekatan perilaku merupakan pendekatan pembelajaran yang digunakan untuk memberi kontribusi terhadap upaya pengendalian perilaku hoaks melalui penggunaan media sosial agar semakin tepat-guna, baik oleh diri mereka sendiri maupun komunitas atau kelompok masyarakat serta institusi yang berwenang. sedangkan pendekatan kognitif merupakan sebuah pendekatan pembelajaran yang lebih fokus pada 


\section{Mahmud Zain}

pikiran. ${ }^{5}$ Oleh karena itu pembelajaran melalui pendekatan koginitif dalam mengedukasi mencegah penyebaran hoaks menjadi penting sebagaimana yang dikemukan oleh Jhon W Santrock terdapat empat pendekatan utama yaitu pendekatan kognitif sosial, pengolahan informasi, kognitif konstruktivis dan konstruktivis sosial.

\section{Temuan Penelitian dan}

\section{Pembahasan}

1. Psikologi Pendidikan dan Hoaks

Dalam melaksanakan pembangunan sumber daya manusia terdapat tiga unsur utama yang harus diperhatikan oleh sebuah bangsa yaitu: pendidikan, kesehatan dan ekonomi. ${ }^{6} \quad$ Sementara proses pelaksanaan dalam dunia pendidikan sangat kompleks karena terdapat beberapa unsur didalamnya antara lain pendidik, peserta didik,

\footnotetext{
5 Jhon W. Santrock, Psikologi Pendidikan (Asia: Mc Graw Hill, 2017), 245.

6 Tukiran, Sumber Daya Manusia Tantangan Masa Depan, (Yogyakarta : Pskk Ugm, 2007), 65.
}

tujuan pendidikan, materi, metode, dan alat pendidikan. Untuk mengimplemntasikan unsur unsur tersebut maka dibutuhkan profesionalitas dari para penyelenggara pendidikan dengan mempertimbangkan aspek psikologi pendidik, peserta didik dan lain sebagainya.

Psikologi pendidikan merupakan cabang psikologi yang membahas tentang pemahaman pengajaran dan pembelajaran di lingkungan pendidikan. Psikologi pendidikan di pelopori oleh William James dan Jhon dewey. Jhon Dewey mengatakan bahwa anak sebagai pembelajar aktif, pendidikan anak secara keseluruhan dan memberi ruang pada anak untuk dapat beradaptasi terhadap lingkungannya serta semua anak berhak untuk mendapatkan pendidikan yang kompeten.

Dalam perkembangannya psikologi pendidikan memberikan peluang yang begitu besar pada keterampilan peserta didik untuk mempertajam penalaran sekaligus sosio-emosional dari kehidupan 
peserta didik dalam konteks budaya dan perilakunya.

Peserta didik sebagai anak bangsa diharapkan dapat bersaing dalam meingkatkan prestasi karena generasi muda memiliki potensi yang besar dalam pembangunan nasional khusunya dalam pemberdayaan sumber daya manusia serta diberi peluang untuk turt memikirkan dan melaksanakan berbagai kegiatan yang akan berdampak positif utnuk pembangunan bangsa dan negara dimasa depan. ${ }^{7}$

Namun hal itu tidak dapat terlakasana dan terwujud apabila tidak di dorong oleh aspek keterampilan karena keterampilan dalam menggunakan teknologi merupakan salah satu faktor pendukung pembelajaran. Untuk mewujudkan harapan tersebut para pemimpin

7 Ambo enre Abdullah, Pendekatan psikologi pendidikan anak, (Yogyakarta: Pustaka Timur, 2006), 124. pendidikan memberikan sebuah solusi alternative agar pendidik mendorong peserta didik menjadi pembelajar aktif dan konstruktif sebagaimana yang dibutuhkan dalam penggunaan teknologi secara efektif, cepat dan cermat. Akan tetapi Hilgrad memberikan pandangan lain bahaw untuk memahami objek pendidikan maka harus menggunakan pendekatan ilmu perilaku mengenai pembeajaran walaupun kemudian gagasan tersebut tidak banyak digunakan karena menurut hilgrad tidak mengarah pada tujuan yang nyata bagi para pendidik. ${ }^{8}$

Hoaks dalam Bahasa Indonesia berarti berita bohong, informasi palsu, atau kabar dusta. Istilah hoax adalah usaha untuk menipu atau mengakali pembaca/pendengarnya untuk mempercayai sesuatu, pa-

\footnotetext{
${ }^{8}$ Jhon W. Santrock, Psikologi Pendidikan (Asia: Mc Graw Hill, 2017), 5.
} 


\section{Mahmud Zain}

dahal sang pencipta berita palsu tersebut tahu bahwa berita tersebut adalah palsu. Salah satu contoh pemberitaan palsu yang paling umum adalah mengklaim sesuatu barang atau kejadian dengan suatu sebutan yang berbeda dengan barang/ kejadian sejatinya. ${ }^{9}$

Penyebaran hoaks yaitu untuk membuat opini publik, menggiring opini publik, membentuk persepsi juga untuk bufing fun yang menguji kecerdasan dan kecermatan pengguna media sosial. Tujuan penyebaran hoax bermacam macam akan tetapi pada umumnya penyebaran hoaks sebagai bahan lelucon atau sekedar iseng, menjatuhkan pesaing (black campaign), promosi dengan penipuan. Namun fenomena tersebut menyebabkan banyak penerima hoax terpancing untuk segera menyebarkan kepada orang lain sehingga informasi hoax ini dengan cepat tersebar luas tanpa

9 Dedi Rianto Rahadi, "Perilaku Pengguna Dan Informasi Hoax Di Media Sosial", Jurnal Manajemen \& Kewirausabaan, Vol. 5, No. 1 (2017), 61. mengecek kebenaran informasi yang di sebarkan dan mengakibatkan dampak negative bagi yang menerima maupun yang menyebarkannnya.

2. Peran Psikologi Pendidikan Sebagai Upaya Meredam Penyebaran Hoaks

Kecanggihan teknologi mendukung setiap individu di tengah masyarakat untuk menjadi bagian dari transformasi kabar secara langsung di media sosial. Mirisnya, sebagian besar pengguna media sosial juga memiliki tingkat literasi yang rendah, khususnya pada aspek kemampuan melakukan verifikasi atas sebuah informasi. ${ }^{10}$

Perilaku manusia dalam konteks social dan buadaya diatur oleh aturan sebagaimana yang dijelaskan seorang tokoh psikologi sosial oleh Stanley Milgram dia mengatakan bahwa "kita semua

10 Andi Fadli, "Etika Dan Tanggung Jawab Jurnalis Studi Pemberitaan Hoax Melalui Media Online di Kota Makassar", Jurnalisa, Vol. 04, No. 2 (November, 2018), 188. 
Vol. 12, No. 1, April 2019

p-ISSN:2086 -0749

e-ISSN:2654-4784

adalah mahluk rapuh yang terikat pada jarring-jaring social yang membatasi gerak kita". ${ }^{11}$ Perilaku manusia diatur oleh norma social dan setiap masyarakat memiliki norma norma mengenai segala hal yang dialami oleh manusia misalnya mendidik anak, mengambil keputusan dan berperilaku di tempat umum.

Mendidik anak di negara Indonesia selain dilakukan oleh orang tua juga dilakukan oleh pendidik di suatu lembaga pendidikan. Lembaga pendididkan mempunyai tanggung jawab yang sangat besar dalam proses pembentukan karakter dan kepribadian peserta didik hal ini dikarenakan masyarakat sudah mempercayai anak mereka akan di didik oleh tenaga profesional dalam sebuah institusi pendidikan. Melalui lembaga pendidikan yang

11 Wade, Psikologi (Jakarta: Penerbit Erlangga), 298. bersangkutan proses edukasi intelektual, emosional dan spiritual akan terbentuk karena sesungguhnya pada saat itulah mulai tersemainya karakter karakter yang terbaik sebagaimana yang diharapkan oleh masyarakat luas. ${ }^{12}$

Dalam membentuk perilaku manusia sekolah menjadi bagian terpenting dalam merawat generasi muda oleh karena itu sekolah harus berperan aktif dalam memastikan bahwa peserta didik menguasi teknologi ${ }^{13}$ terlebih dalam upaya meredam penyebaran hoaks di tengah masyarakat melalui media sosial sehingga generasi muda tidak terprovokasi dan terpengaruhi dalam tindakan tersebut dengan beberapa standar yang harus dilakukan sebagaimana berikut:

12 Abd Majid, Pendidikan Berbasis Ketubanan Membangung Manusia Berkarakter (Bogor : Ghalia Indonesia, 2014), 38.

13 Jhon W. Santrock, Psikologi Pendidikan (Asia: Mc Graw Hill, 2017), 148. 


\section{Mahmud Zain}

Pertama yaitu standar untuk penguasaan teknologi peserta didik. Bahwa masyarakat internasional untuk teknologi dalam bidang pendidikan telah me-ngembangkan enam standar teknologi untuk peserta didik: peserta didik menunjukkan pemikiran kreatif, membangun pengetahuan dan mengembangkan produk produk inovatif dengan teknologi, peserta didik menggunakan media digital dan konteks untuk bekerja sama termasuk di kejauhan untuk meningkatkan pembelajaran, peserta didik menerapkan alat alat digital untuk mengum-pulkan, mengevaluasi dan menggunakan informasi, peserta didik terlibat dalam pemikiran kritis untuk merencanakan dan melaksanakan penelitian, mengelola proyek, memecahkan masalah dan membuat keputusan yang efektif dengan menggunakan teknologi tepat guna, peserta didik meningkatkan pemahaman mereka tentang isu-isu manusia, sosial, serta budaya yang melibatkan teknologi dan menunjukkan perilaku etis, peserta didik memahami operasi teknologi dan konsep.

Kedua yaitu Mengajar, pembelajaran dan teknologi. Dalam proses pem-belajaran teknologi dibutuhkan waktu perhatian khusus dalam rangka untuk me-ningkatkan pengajaran dan pembelajaran terutama ketika mendidik anak walaupun orang dewasa mendidik anak dengan menggunakan beragam transmisi sosial sekalipun ia seorang genius kreatif. ${ }^{14} \quad$ Pemahaman penggunaan teknologi ter-hadap peserta didik dalam meredam penyebaran hoaks dapat dilakukan melalui mengevaluasi topik pemahaman, pikirkan mengenai yang harus dipahami peserta didik tentang suatu topik tertentu, perhatian cara peserta didik mengembangkan dan menunjukkan pemahaman dalam menggunakan media sosial, pertimbangan cara peserta didik dan pendidik assesment pembelaja-

\footnotetext{
${ }^{14}$ Jean Piaget, Psikologi Anak. (Yogyakarta: Pustaka Pelajar, 2018), 4.
} 
Vol. 12, No. 1, April 2019

p-ISSN:2086 -0749

e-ISSN:2654-4784

ran dan memberikan upaya refleksi peserta didik oleh pendidik agar dapat belajar bersama sama sehingga tujuan dapat tercapai.

Proses pembelajaran yang melibatkan peserta didik untuk ikut serta dan aktif dalam pembelajaran akan memberikan efek yang sangat positif dimasa yang akan datang hal ini dikarenakan informasi yang diterima oleh peserta didik adalah proses perekaman yang akan mudah di ingat karena informasi yang diberikan bagian proses pemrosesan informasi dalam otak atau disebut dengan memori jangka panjang. ${ }^{15}$

Adapun tahapan mengintegrasikan teknologi dalam pengajaran kelas dalam proses pengajaran di kelas sering kali terjadi seperti sebagaimana berikut: a. belum memiliki kesadaran tentang pengguna teknologi sehingga mem-

15 Robert E Slavin, Psikologi Pendidikan Teori Dan Praktik (Jakarta, Indeks, 2011), 228. ilih untuk menghindari teknologi dengan demikian maka peserta didik menjadi korban dari pendidik akibat dari gagapnya pendidik dalam teknologi sehingga penyebaran hoaks yang dilakukan peserta didik tidak dapat dihindari. b. pendidik pada saat ini sedang berusaha untuk memahami dan mempelajari aspek aspek dasar teknologi tetapi seringkali putus asa sehingga target yang dicapai belum berhasil. Oleh karena itu Pendidikan terhadap pendidik perlu dilakukan oleh penyelenggara Pendidikan atau pemerintah Pendidikan dan kebudayaan dalam rangka mempercepat pertumbuhan dan kemajuan pendidik dalam menggunakan teknologi dan informasi. c. pendidik pada awalnya menggunakan teknologi dan tentang situasi serta waktu tertentu untuk menggunakannya. Penambahan fasilitas dan perubahan kurikulum di suatu Lembaga diperlukan ino- 


\section{Mahmud Zain}

vasi yang memau teerhadap proses pembelajaran yang dilakukan. d. pendidik harus mendapatkan kepercayaan dalam menggunakan teknologi untuk tugas-tugas dan merasa lebih nyaman dalam menggunakannya. e. pendidik pada saat ini berpikir tentang teknologi sebagai suatu yang dapat membantu dia dan tidak lagi percaya diri dalam menggunakannya. f. pendidik dapat menggunakan teknologi sebagai media pembelajaran yang efektif di seluruh kurikulum untuk mencapai tujuan.

Selain penguatan pengembangan pengetahuan terhadap pendidik juga harus diberikan kepada peserta didik untuk diajak mencintai terhadap dunia literasi. Baca buku dan memiliki banyak referensi akan menjadi salah satu benteng terkuat daripada anak didik agar bisa bebas dari ancaman hoax. Penduduk Indonesia masih minim tentu hal ini menjadi ironis sekali. Tidak salah jika bangsa ini terancam dengan sangat terbuka dari hoax. Karena persoalan tingkat literasi yang sangat jauh dari yang diharapkan. Harapannya kedepan peran pendidik terhadap peserta dididk mutlak untuk perhatikan, bahwa dorongan dari para pendidik agar bisa mencintai buku untuk bisa terhidndar dari hoaks.

Peserta didik diajak untuk cerdas dalam bermedia sosial. Menggunakan media sosial sebagai produksi. Bukan hanya konsumsi dengan memberikan wawasan tentang berwirausaha atau memasarkan produknya lewat internet. Bukan malah terlibat dalam saling serang antara satu kelompok dengan kelompok lainnya. Pada kerangka inilah sebenarnya anak didik tidak hanya menjadi kelompok yang menerima dari media social. ${ }^{16}$

\section{Simpulan}

Psikologi pendidikan mempunyai peran yang begitu besar dalam upaya meredam penyebaran

\footnotetext{
16 Abdul Ghoni, "Role Model Pendidikan Untuk Melawan Hoax", Subulana, Vol. 2 No. 2 (April, 2019), 5.
} 
hoaks yang meresahkan masyarakat yaitu berupa edukasi teknologi di dunia pendidikan. Masyarakat intenasional telah bersepakat bahwa teknologi dalam Pendidikan harus dikembangkan dengan 6 standar teknologi untuk peserta didik yaitu a. Kreativitas dan inovatif b. Komunikasi dan Kolaborasi c. Penelitian dan Informasi Kefasihan d. Membuat berpikir kritis e. Kewarganegaraan digital f. Operasi teknologi dan konsep. Dengan demikian upaya meredam penyebaran hoaks dapat dilakukan

\section{Daftar Pustaka}

Abdullah, Ambo enre. Pendekatan psikologi pendidikan anak, (Yogyakarta: Pustaka Timur, 2006)

Eriyanto, Analisis Wacana Pengantar Analisis Teks Media, (Yogyakarta: Lkis, 2001)

Fadli, Andi. "Etika Dan Tanggung Jawab Jurnalis Studi Pemberitaan Hoax Melalui Media
Online di Kota Makassar", Jurnalisa, Vol. 04, No. 2 November, 2018

Ghoni, Abdul. "Role Model Pendidikan Untuk Melawan Hoax", Subulana, Vol. 2 No. 2 April, 2019

Majid, Abd. Pendidikan Berbasis Ketubanan Membangung Manusia Berkarakter (Bogor : Ghalia Indonesia, 2014)

Monohevita, Lusiana. "Stop Hoax! Setelah Tahu Sebuah Informasi Adalah Hoax, Apakah Anda Masih Ingin Menyebarkannya?", Uilib.Berkala, Vol. 3, No. 3, September, 2017

Nugraha, Ari Rizki. Gerakan Literasi Media Di Sekolah Sebagai Upaya Meminimalisir Penyebaran Hoaks Melalui Media Sosial, (Bandung: Universitas Pendidikan Indonesia, 2018)

Piaget, Jean. Psikologi Anak, (Yogyakarta: Pustaka Pelajar, 2018)

Rahadi, Dedi Rianto. 2017 "Perilaku Pengguna Dan Informasi Hoax Di Media Sosial", 


\section{Mahmud Zain}

Jumal Manajemen \&

Kewirausahaan, Vol. 5, No. 1

Rahmat, Jalaluddin. Psikologi Komunikasi (Bandung : Remaja Rosdakarya , 2008)

Santrock, Jhon W. Psikologi Pendidikan (Asia: Mc Graw Hill, 2017)

Slavin, Robert E. Psikologi Pendidikan Teori Dan Praktike (Jakarta, Indeks, 2011)

Tukiran, Sumber Daya Manusia Tantangan Masa Depan, (Yogyakarta : Pskk Ugm, 2007)

Wade, Psikologi, Jakarta: Penerbit Erlangga, 2014) 